ISSN 1392-3196 / e-ISSN 2335-8947

Zemdirbyste-Agriculture, vol. 104, No. 2 (2017), p. 179-184

DOI 10.13080/z-a.2017.104.023

\title{
Evaluation of chitinase enzyme in fungal isolates obtained from golden potato cyst nematode (Globodera rostochiensis)
}

\author{
Khadijeh ABBASI ${ }^{1}$, Doustmorad ZAFARI ${ }^{1}$, Robert WICK ${ }^{2}$ \\ ${ }^{1} \mathrm{Bu}-\mathrm{Ali}$ Sina University \\ Hamedan, Iran \\ E-mail: Zafari_d@yahoo.com \\ ${ }^{2}$ Stockbridge School of Agriculture, University of Massachusetts Amherst \\ 360 Campus Center Way Amherst, MA 01003-9248, USA
}

\begin{abstract}
The structure of nematode eggshell indicates that proteases and chitinases are necessary for infection by nematophagous fungi, and most of them produce these enzymes. Therefore the aim of this study was to assay chitinase activity in 34 isolates of various species of fungi obtained from golden potato cyst nematode (Globodera rostochiensis), as the most important potato pest, over two days of fungal growth (24 and $96 \mathrm{~h}$ ). Chitinase specific activity was determined by measuring the release of reducing saccharides from colloidal chitin by the $N$-acetylglucosamine-dinitrosalicylate method at $540 \mathrm{~nm}$. Colorimetry based on image processing technique was used to discover colour changes in minimal synthetic medium for validation of chitinase activity. The 34 isolates were identified based on morphological and molecular features including internal transcribed spacer (ITS) regions of ribosomal DNA. Results of the chitinase specific activity measurement showed the chitinase specific activity in all of them for $96 \mathrm{~h}$ was higher than for $24 \mathrm{~h}$. Among isolates, the maximum and minimum chitinase specific activity respectively belonged to isolate $154\left(0.56 \mathrm{U} \mathrm{mg}^{-1}\right)$ and isolate $6\left(0.15 \mathrm{U} \mathrm{mg}^{-1}\right)$ in $24 \mathrm{~h}$, also isolate $113\left(1.02 \mathrm{U} \mathrm{mg}^{-1}\right)$ and isolate $6\left(0.40 \mathrm{U} \mathrm{mg}^{-1}\right)$ in $96 \mathrm{~h}$. Colorimetric results confirmed that enzyme activity was associated with colour changes. The 34 fungal isolates were classified in 11 genera most of which belonged to Fusarium. Finally, two isolates, 113 (Fusarium oxysporum) and 154 (Trichoderma atroviridae), with the highest chitinase enzyme activity are introduced as potent isolates to control the golden potato cyst nematode that can be used for chitinase enzyme production which is supposed to be used in commercial formulation.
\end{abstract}

Key words: chitinase, fungi, Globodera rostochiensis, potato.

\section{Introduction}

The potato (Solanum tuberosum L.) is the fifth most valuable crop after wheat, rice, corn and barley in the world (Zarghani et al., 2014). Iran is the third-largest producer of potato in Asia, where the production rate in 2015 was estimated about 5 million tons (Ahmadi et al., 2015).

The golden cyst nematode, Globodera rostochiensis (Wollenweber, 1923; Behrens, 1975), is the most destructive pathogen of potato (Gitty et al., 2011). Until recent years the use of chemical pesticides has been one of the most reliable methods for the management of the nematodes (Saifullah, Khan, 2014). However according to international agreements, the use of chemical nematicides in many countries has been banned because of the deleterious effects on humans, the environment, reduction of the $\mathrm{C}: \mathrm{N}$ ratio of soil, persistence in soil, pollution of groundwater and the high price of the nematicides (Dong et al., 2004).
Biological control of plant parasitic nematodes is a good management strategy (Sharon et al., 2009). Many natural enemies of plant parasitic nematodes occur that may be useful for biological control. These include pathogens, predators, competitors and antagonists of which $76 \%$ are fungi (Khezri Nezhad, 2004). The fungal antagonists have been most extensively studied and are considered the most applicable for biological control of nematodes. The use of biological agents to control of plant-parasitic nematodes is less effective compared with chemical method, but positive result of fungal agents has been encouraging (Nguyen et al., 2007). Tobin et al. (2008) reported that Pochonia chlamydosporia was a good biocontrol agent for the potato cyst nematode. López-Lima et al. (2013) reported that the populations of the potato cyst nematode decreased up to $89 \%$ with Paecilomyces sp. Trichoderma also successfully controlled plant-parasitic nematodes, especially cyst nematodes.

Please use the following format when citing the article:

Abbasi K., Zafari D., Wick R. 2017. Evaluation of chitinase enzyme in fungal isolates obtained from golden potato cyst nematode (Globodera rostochiensis). Zemdirbyste-Agriculture, 104 (2): 179-184 DOI 10.13080/z-a.2017.104.023 
Chitinases, glucanase and protease are considered the most important mechanism for successful biological control of nematodes (Sharon et al., 2001; Safari Motlagh, Samimi, 2013). Saifullah and Khan (2014) explained that Trichoderma harzianum enzymatically penetrated cysts and eggs resulting in death of $G$. rostochiensis. Also Saifullah and Khan (2014) utilizing low-temperature scanning electron microscopy (LTSEM) observed initial infection and the penetration by $T$. harzianum to cyst and egg wall. Manzanilla Lopez et al. (2013) stated that $P$. chlamydosporia is one of the most important fungi for the biocontrol of plant parasitic nematodes. Santos et al. (2013) demonstrated that chitinase and protease of $P$. chlamydosporia was involved in control of the potato cyst and root-knot nematodes.

Plant parasitic nematodes cause important economic losses in agricultural crops. Activity of the fungal egg-parasites leads to immobility and death of the embryos and results in a reduction of nematode population density. The disintegration of nematode eggs can only be caused by enzymatic action. Knowledge of various aspects of chitinolytic enzymatic systems allows the development of a new generation of chitinases and the design of better strategies of biological control (Gortari, Hours, 2008). Fungal chitinases are produced by nematophagous and entomopathogenic fungi to aid infection (Tikhonov et al., 2002). Because chitin is a dominant component of the eggshell in nematodes, the use of chitinase producing fungi is a good strategy for biological control of the golden potato cyst nematode (Morton et al., 2004). In the present study, we evaluated the chitinase production by various nemathophagous fungi isolated from the golden potato cyst nematode, as the most important potato pest.

\section{Materials and methods}

Fungal isolates. Thirty four fungal isolates were recovered from infected eggs of the golden potato cyst nematode (Globodera rostochiensis) in Hamedan, Iran, in 2015. The fungi were grown on PDA (potato dextrose agar) at $25^{\circ} \mathrm{C}$.

Morphological and molecular identification. All of the isolates were identified based on morphological (Nagami et al., 2006) and molecular features including internal transcribed spacer (ITS) regions (ITS1, ITS2 and $5.8 \mathrm{~S}$ gene) of ribosomal DNA.

DNA extraction. For DNA extraction from 34 isolates, fungal mycelia were grown on potato dextrose broth (PDB) for 7 days, then were lyophilized by freeze-drying. Total genomic DNA was extracted from lyophilized mycelia with a QIAGEN DNeasy Plant Mini Kit (Germany). The extracted genomic DNA was diluted in $50 \mu \mathrm{l}$ distilled water and checked in terms of quality and quantity by means of both $0.8 \%$ agarose gel electrophoresis and spectrophotometer technique based on absorption at $260 \mathrm{~nm}$.

Polymerase chain reaction $(P C R)$ amplification. ITS regions (ITS1, ITS2 and 5.8S gene) of ribosomal DNA were amplified with the ITS1 (forward primer) and ITS4 (reverse primer) primers. PCR amplifications were performed using a thermocycler (Corbett Research, Australia) with total reaction volume of $25 \mu$ l. In this study, Takara EmeraldAmp GT PCR Master Mix to amplify the ITS region for sequencing was used. Final component concentrations per reaction containing $12.5 \mu \mathrm{l}$ Takara
EAGT Master Mix (optimized mix of Taq polymerase, $\mathrm{MgCl}_{2}$ and dNTPs), $2.5 \mu \mathrm{l}$ forward primer $(5 \mu \mathrm{M}), 2.5 \mu \mathrm{l}$ reverse primer $(5 \mu \mathrm{M}), 6.5 \mu \mathrm{l}$ sterile distilled DNA-grade water, $1 \mu$ template DNA (10-500 ng $\left.\mu^{-1}\right)$. Amplification reactions were carried out using the following cycle profile: initial denaturation at $94^{\circ} \mathrm{C}$ for $1 \mathrm{~min}$ followed by 35 cycles including; denaturation at $94^{\circ} \mathrm{C}$ for $1 \mathrm{~min}$, annealing of primer $51^{\circ} \mathrm{C}$ for $1 \mathrm{~min}$, extension at $72^{\circ} \mathrm{C}$ for $1 \mathrm{~min}$ and a final extension at $72^{\circ} \mathrm{C}$ for $8 \mathrm{~min}$. PCR products were separated by electrophoresis technique using $1 \%$ agarose gel in $1 \mathrm{X}$ Tris-Borate-EDTA (TBE) buffer by adding $12 \mu \mathrm{l} \mathrm{SYBR}$-safe $10,000 \mathrm{X}$ concentrate DNA stain to melted agarose before running of the gel and finally visualized under ultraviolet illuminator. SYBRsafe is a non-toxic chemical that is used to visualize DNA under UV light in agarose gel electrophoresis. The gel image was recorded using BioDoc gel Documentation System (UVP, USA).

Then ExoSAP-IT for PCR product cleanup was done. ExoSAP-IT reagent treats PCR products ranging in size from less than $100 \mathrm{bp}$ over $20 \mathrm{~kb}$ with absolutely no sample loss by removing unused primers and nucleotides. To purify the samples, $5 \mu$ post-PCR product was mixed with $2 \mu \mathrm{l}$ ExoSAP-IT reagent for a combined $7 \mu \mathrm{l}$ reaction volume, and incubated at $37^{\circ} \mathrm{C}$ for $15 \mathrm{~min}$ to degrade the remaining primers and nucleotides. Finally the samples were incubated at $80^{\circ} \mathrm{C}$ for $15 \mathrm{~min}$ to inactivate the ExoSAP-IT reagent.

The ITS1, ITS2 and $5.8 \mathrm{~S}$ sequences were obtained by sequencing both strands in opposite directions using the PCR amplification primers, ITS1 and ITS4 in Genomics Resource Laboratory at Massachusetts University, USA.

Enzyme assay. Colloidal chitin was prepared following the procedure of Tikhonov et al. (2002). For enzyme assay in liquid media, the 34 isolates were grown in minimal synthetic medium (MSM) $\mathrm{g} \mathrm{l}^{-1}$ : $\left(\mathrm{NH}_{4}\right)_{2} \mathrm{SO}_{4}$, 2.8, urea, $0.6, \mathrm{KH}_{2} \mathrm{PO}_{4}, 4, \mathrm{CaCl}_{2} .2 \mathrm{H}_{2} \mathrm{O}, 0.6, \mathrm{MgSO}_{4}, 0.2$, $\mathrm{FeSO}_{4} .7 \mathrm{H}_{2} \mathrm{O}, 0.01, \mathrm{ZnSO}_{4} \cdot \mathrm{H}_{2} \mathrm{O}, 0.0028$ and $\mathrm{CoCl}_{2} .6 \mathrm{H}_{2} \mathrm{O}$, 0.0032 ) containing colloidal chitin $\left(1 \mathrm{~g} \mathrm{l}^{-1}\right)$ (Zeilinger et al., $1999)$ at $25^{\circ} \mathrm{C}$. The culture medium was filtered through Whatman paper No. 3 filter followed by filtration through $0.2-\mathrm{mm}$ Millipore polydifluoropropilene membranes. The filtrate obtained was analyzed for chitinolytic activity.

Chitinase activity was determined by measuring the release of reducing saccharides from colloidal chitin by the $N$-acetyl-glucosamine-dinitrosalicylate method according to the method described by Monreal and Reese (1969). A reaction mixture containing $200 \mu \mathrm{l}$ $0.5 \%$ chitin provided in citrate phosphate buffer $(0.05 \mathrm{M}$, $\mathrm{pH}=6.6)$ and $200 \mu \mathrm{l}$ enzyme solution was incubated at $37^{\circ} \mathrm{C}$ for $1 \mathrm{~h}$. Then $1 \mathrm{ml}$ of dinitrosalicylic acid reagent (DNS) was added to reaction. The reaction was heated in boiling water for $5 \mathrm{~min}$ and was centrifuged at $6,000 \mathrm{rpm}$ for $5 \mathrm{~min}$ and absorbance at $540 \mathrm{~nm}$ was measured. Protein concentration was determined according to Bradford (1976) with bovine serum albumin (Sigma) as the standard. Chitinase specific activity was calculated from the rate of enzyme activity divided per the mass of total protein. Enzyme assay was done to determine the most promising isolates for biological control of G. rostochiensis 24 and $96 \mathrm{~h}$ after fungal growth.

Data of the chitinase specific activity was subjected to analysis of variance (ANOVA) by software $S A S$, version 9.0 (Statistical Analysis System Institute Inc., USA) in a completely randomized design with three replicates. 
Image processing. The field of digital image processing refers to processing digital images by means of a digital computer. Note that a digital image is composed of a finite number of elements, each of which has a particular location and value. Because digital images are displayed as a discrete set of intensities, the eye's ability to discriminate between different intensity levels is an important consideration in presenting image-processing results. Colour intensity of digital images has 256 levels that all of them could not be seen with human's eyes exactly (Gonzalez, Woods, 2002).

Chitinase enzyme activity causes the colour change in enzyme solution that is indistinguishable by human eyes. As a result, to analyze these phenomena, due to the ability of image processing to detect low colour change levels, this method was used. At first colour images were taken from isolates enzyme solution using a 12.1 MP digital camera Canon SX200is (Japan). Histogram equalization was done to reduce the noise of images using pre-processing algorithms (Gonzalez, Woods, 2002). Then by colour space transformation from RGB (red, green, blue) to HSV (hue, saturation and value) and $\mathrm{L}^{*} \mathrm{a} * \mathrm{~b} *$ using software MATLAB, version $2013 \mathrm{~b}$, the obtained colour components $\left(\mathrm{R}, \mathrm{G}, \mathrm{B}, \mathrm{H}, \mathrm{S}, \mathrm{V}, \mathrm{L}^{*}, \mathrm{a}^{*}\right.$ and $\mathrm{b}^{*}$ ) were evaluated to find the best colour component that can confirm the chitinase activity colour changes.

\section{Results and discussion}

The 34 fungal isolates were identified according to morphological and molecular features and were classified in 11 genera (Alternaria, Beauveria, Candida, Cylindrocarpon, Fusarium, Humicola, Lecanicillium, Paecilomyces, Plectosphaerella, Trichoderma and Ulocldium) most of which belonged to Fusarium (Table 1). As a producer of a variety of chitinase enzymes, the filamentous fungus, Fusarium spp. can be an important means of biological control for G. rostochiensis. Ibrahim et al. (2009) isolated some fungi including $F$. oxysporum, Aspergillus spp., Rhizoctonia solani, Paecilomyces lilacinus and Verticillium chlamydosporium from Meloidogyne incognita eggs that $F$. oxysporum had the most biocontrol effect on the nematode. Also this result is similar to report of Ruanpanun et al. (2010). They isolated various fungal species from $M$. incognita most of which were Penicillium and Fusarium.

The results of chitinase specific activity showed significant differences not only among isolates but also between two days of fungal growth at the 0.001 level (Table 2). All of the 34 isolates had have chitinase activity and chitinase specific activity in all of the isolates was higher in $96 \mathrm{~h}$ than $24 \mathrm{~h}$. Among these isolates, the maximum chitinase specific activity belonged to isolate 154: T. atroviridae $\left(0.56 \mathrm{U} \mathrm{mg}^{-1}\right)$ and isolate $113:$ F. oxysporum

Table 1. Results of identification of the fungal isolates according to morphological and molecular features

\begin{tabular}{clcl}
\hline Isolate No. & \multicolumn{1}{c}{ Genus and species } & Isolate No. & \multicolumn{1}{c}{ Genus and species } \\
\hline 6 & Candida parapsilosis & 83 & Fusarium oxysporum \\
8 & Fusarium equiseti & 93 & Candida sp. \\
11 & Plectosphaerella sp. & 97 & Fusarium oxysporum \\
12 & Fusarium oxysporum & 109 & Fusarium solani \\
14 & Fusarium solani & 111 & Candida parapsilosis \\
18 & Fusarium solani & 113 & Fusarium oxysporum \\
19 & Candida parapsilosis & 123 & Fusarium oxysporum \\
27 & Alternaria alternata & 129 & Fusarium equiseti \\
30 & Alternaria alternata & 140 & Candida parapsilosis \\
40 & Plectosphaerella cucumerina & 141 & Humicola grisea \\
49 & Cylindrocarpon olidum & 144 & Candida parapsilosis \\
52 & Ulocldium dauci & 145 & Fusarium oxysporum \\
56 & Fusarium equiseti & 147 & Fusarium oxysporum \\
62 & Fusarium solani & 151 & Beauveria bassiana \\
63 & Fusarium solani & 152 & Lecanicillium muscarium \\
66 & Fusarium equiseti & 153 & Paecilomyces sp. \\
76 & Candida parapsilosis & 154 & Trichoderma atroviridae \\
\hline
\end{tabular}

Table 2. Analysis of variance (mean square) of the chitinase specific activity in 24 and $96 \mathrm{~h}$ after fungal growth among 34 isolates

\begin{tabular}{cccc}
\hline Sources of variance & $\mathrm{df}$ & Specific activity $(24 \mathrm{~h}) \mathrm{U} \mathrm{mg}^{-1}$ & Specific activity $\left(96 \mathrm{~h}^{-} \mathrm{U} \mathrm{mg}^{-1}\right.$ \\
\hline Isolate & 33 & $0.03932^{* * *}$ & $0.06152^{* * *}$ \\
Error & 68 & 0.00036 & 0.00889 \\
$\mathrm{CV} \%$ & & 8.10 & 14.49 \\
\hline
\end{tabular}

$\mathrm{CV}-$ coefficient of variation, $\mathrm{df}-$ degree of freedom; $* * *$ - significant at 0.001 level

$\left(1.02 \mathrm{U} \mathrm{mg}^{-1}\right)$ in $24 \mathrm{~h}$ and $96 \mathrm{~h}$, respectively. Also isolate 6: C. parapsilosis $\left(0.15 \mathrm{U} \mathrm{mg}^{-1}\right.$ and $\left.0.40 \mathrm{U} \mathrm{mg}^{-1}\right)$ in $24 \mathrm{~h}$ and $96 \mathrm{~h}$ had the minimum chitinase specific activity (Figs. 1 and 2).

In this study, among the 34 isolates of various species of fungi, two well-known biocontrol genera Trichoderma and Fusarium had the highest enzymatic activity. These fungi were previously reported by Sankaranarayanan et al. (2002), Safari Motlagh and Samimi (2013) and Saifullah and Khan (2014) as important biocontrol agents on $G$. rostochiensis. Also Safavi et al. (2010) have stated that several species of fungi including Zoophthora radicans, Metarhizium anisopliae, Fusarium sp. and $B$. bassiana are potent biocontrol agents of plant 


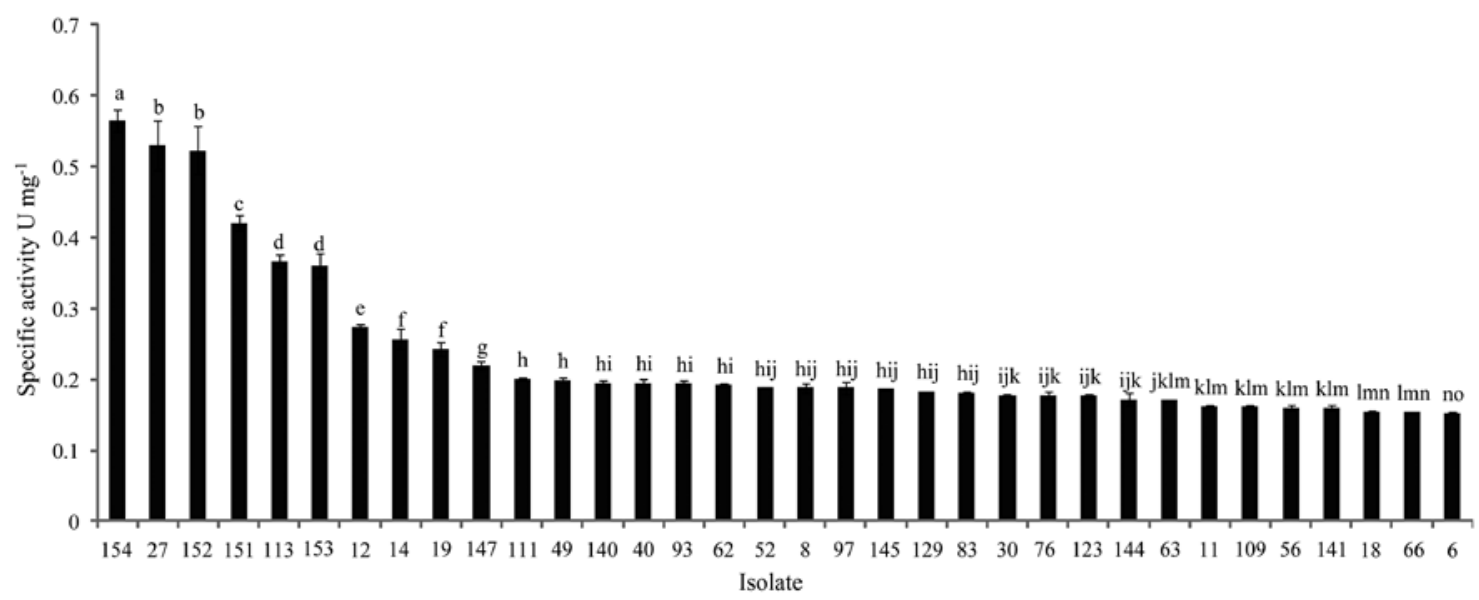

Figure 1. Chitinase specific activity of culture filtrates of 34 isolates in the minimal synthetic medium (MSM) in $24 \mathrm{~h}$

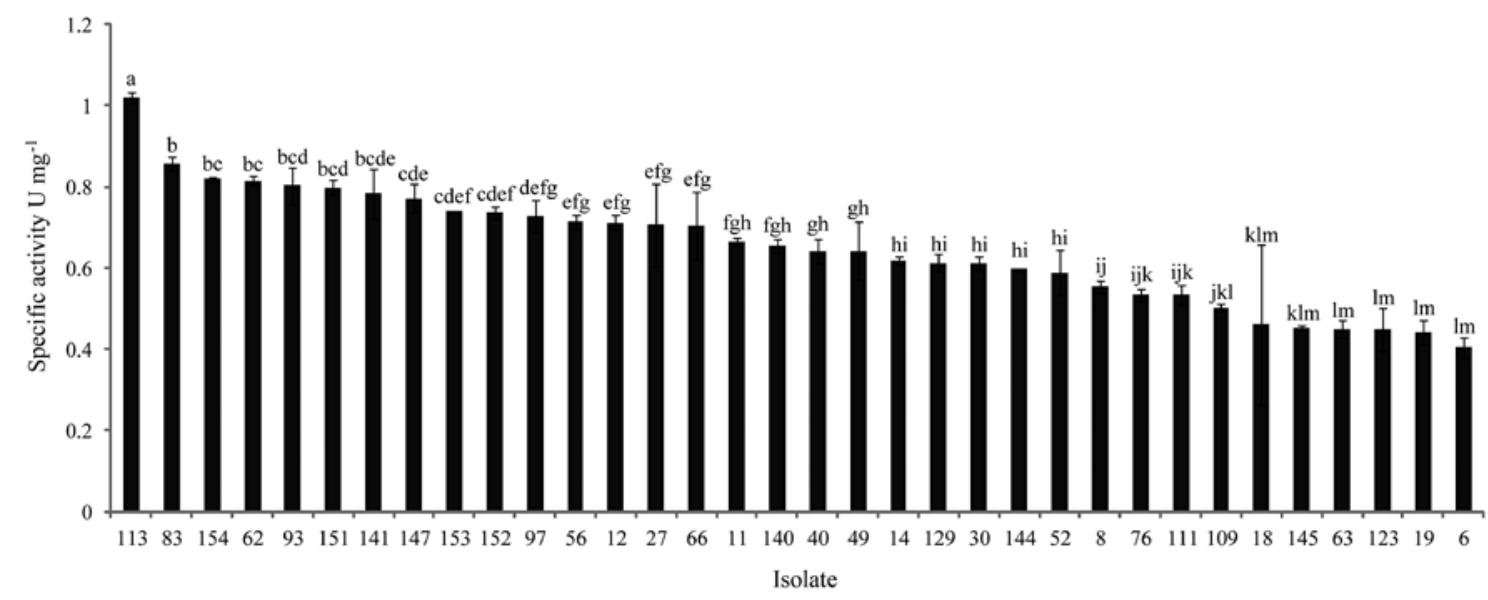

Figure 2. Chitinase specific activity of culture filtrates of 34 isolates in the minimal synthetic medium (MSM) in $96 \mathrm{~h}$

pathogenic fungi and arthropods that can infect different insect species in screen house or field conditions.

The results of the linear regression of enzyme assay for two days, $24 \mathrm{~h}$ and $96 \mathrm{~h}$, showed there is a good correlation between two conditions and the coefficient of determination was $R^{2}=0.7$ (Fig. 3). This coefficient showed that biological activity does not necessarily follow a linear relationship. But we can see relative changes between chitinase specific activities in $96 \mathrm{~h}$ than $24 \mathrm{~h}$ in 34 isolates had uptrend (Fig. 4).

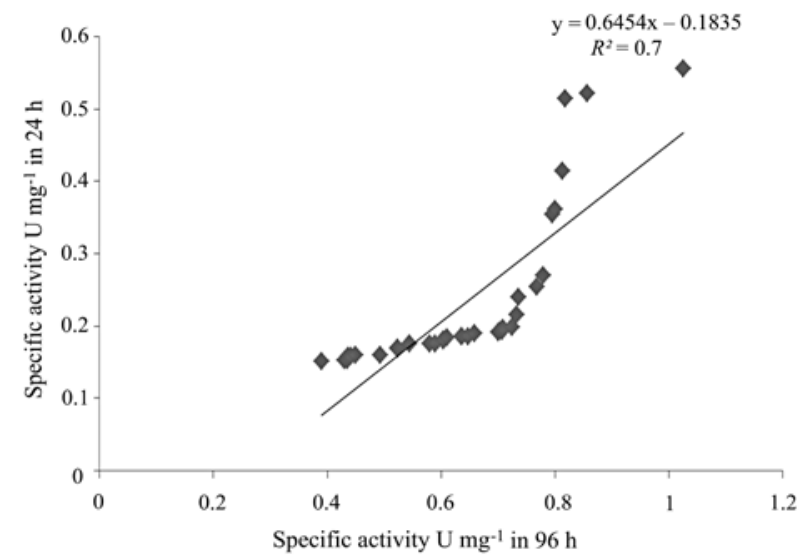

Figure 3. Regression relationship between chitinase specific activity in $24 \mathrm{~h}$ and $96 \mathrm{~h}$ in 34 isolates

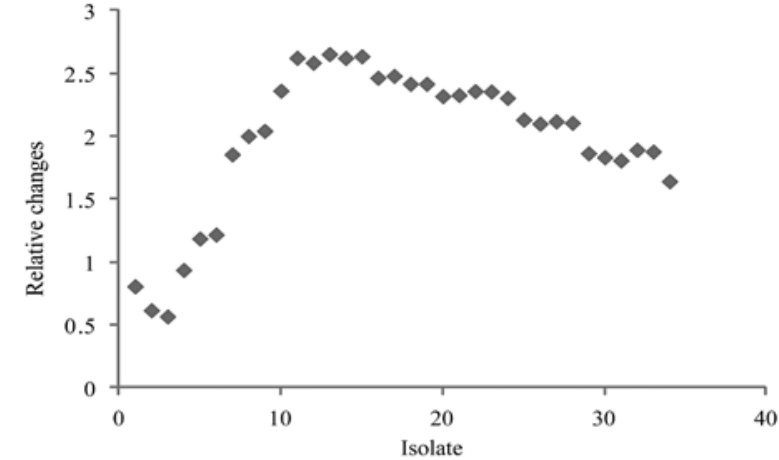

Figure 4. Relative changes between chitinase specific activity in $24 \mathrm{~h}$ and $96 \mathrm{~h}$ in 34 isolates

Image processing technique for colorimetry of the samples confirmed the results of chitinase activity. Results showed that among all 9 colour components (RGB, HSV and $\mathrm{L}^{*} \mathrm{a} \mathrm{b}^{*}$ ), $\mathrm{L}^{*}$ had maximum correlation coefficient $\left(R^{2}=0.97\right)$ with enzyme activity (Fig. 5). This component shows intensity of colour between 0 (black) to 100 (white) and confirms that intensity colour of isolates with high chitinase activity is low. This means that increase of chitinase activity causes darkening of enzyme solution colour.

Results showed that isolate 113 (F. oxysporum with maximum chitinase activity equal to $1.02 \mathrm{U} \mathrm{mg}^{-1}$ ) 


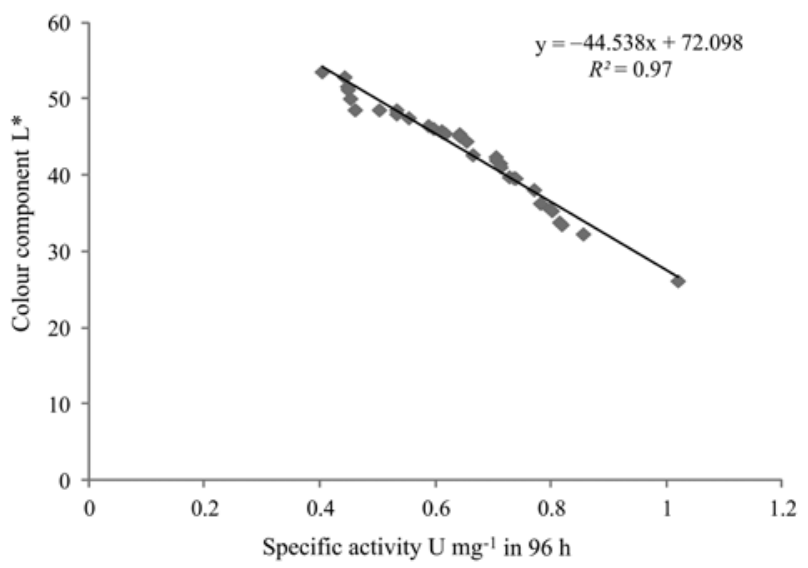

Figure 5. Regression relationship between chitinase specific activity in $96 \mathrm{~h}$ and colour component $\mathrm{L}^{*}$ (image processing) in 34 isolates

had minimum $\mathrm{L}^{*}$ component value and isolate 6 (C. parapsilosis with minimum chitinase activity equal to $0.40 \mathrm{U} \mathrm{mg}^{-1}$ ) had maximum $\mathrm{L}^{*}$ component value.

\section{Conclusions}

1. Based on morphological and molecular features, the 34 isolated fungi from Globodera rostochiensis were classified in 11 genera most of which belonged to Fusarium. As a producer of a variety of chitinase enzymes, the filamentous fungus, Fusarium spp., can be an important means of biological control for this nematode.

2. According to chitinase specific activity assay in 34 isolates of various species of fungi obtained from infected golden potato cyst nematode over two days of fungal growth (24 h and $96 \mathrm{~h})$, isolates 154: Trichoderma atroviridae and 113: Fusarium oxysporum in 24 and $96 \mathrm{~h}$ had high activity, respectively. Also isolate 6: Candida parapsilosis in these two days had the minimum chitinase specific activity.

3. Use of image processing technique confirmed that there is a good relationship between enzyme activity and colour intensity of enzyme solution in $96 \mathrm{~h}$. The colour of solution for isolates with high enzyme activity is darker than for isolates with low enzyme activity.

4. In general, the successful isolates, 154: T. atroviridae and 113: $F$. oxysporum in chitinase enzyme activity in the present study can be used for mass production of this enzyme which is supposed to be used in commercial formulation and also will be able to control golden potato cyst nematode.

\section{Acknowledgements}

Thanks to Plant Pathology Department of Massachusetts University for supplying molecular researches and providing sequencing in genomics resource laboratory.

Received 08092016

Accepted 27022017

\section{References}

Ahmadi K., Gholizadeh H., Ebadzadeh H., Hosseinpour R., Hatami F., Fazli B., Kazemian A and Rafiei M. 2015. Agricultural crops statistics. Ministry of Agriculture, Department of Planning and Economy, Center for Information and Communication Technology, 1: 158
Bradford M. M. 1976. A rapid and sensitive method for quantification of microgram. Analytical Biochemistry, 72: $248-254$ https://doi.org/10.1016/0003-2697(76)90527-3

Dong J. Y., Zhao Z. X., Cai L., Liu S. Q., Zhang H. R., Duan M., Zhang K. Q. 2004. Nematicidal effect of fresh water fungal cultures against the pine-nematode, Bursaphelenchus xylophilus. Fungal Diversity, 15: 125-135

Gitty M., Tanhamaafi Z., Arjmandian A., Pishevar S. 2011. Occurrence of potato golden cyst nematode in Iran and its distribution in Hamedan province. Agricultural Biolotechnology, 10: 53-61

Gonzalez R. C., Woods R. E. 2002. Digital image processing $\left(2^{\text {nd }}\right.$ ed. $)$

Gortari M. C., Hours R. A. 2008. Fungal chitinases and their biological role in the antagonism onto nematode eggs: a review. Mycological Progress, 7: 221-238 https://doi.org/10.1007/s11557-008-0571-3

Ibrahim G. H., Al Rehiayani S. M., Bellal M. M. 2009. Use of biocontrol fungi, Bacillus thuringiensis and organic soil amendment to control root-knot nematode (Meloidogyne incognita) in tomato and eggplant. Mansoura University Journal of Agricultural Sciences, 34: 10761-10770

Khezri Nezhad N. 2004. Evaluation of the biodiversity of nematodes in sugar beet fields and natural infection of sugar beet cyst nematode with antagonistic fungi in West Azerbaijan province: Urmia University master's thesis, $185 \mathrm{p}$.

López-Lima D., Sánchez-Nava P., Carrión G., NúñezSánchez A. E. 2013. 89\% reduction of a potato cyst nematode population using biological control and rotation. Agronomy for Sustainable Development, 33 (2): 425-431 https://doi.org/10.1007/s13593-012-0116-7

Manzanilla Lopez R. H., Esteves I., Fintti Sialer M. M., Hirsch P. R., Ward E., Devonshire J., Hidalgo Diaz L. 2013. Pochonia chlamydosporia: advances and challenges to improve its performance as a biological control agent of sedentary endo-parasitic nematodes. Journal of Nematology, 45: 1-7

Monreal J., Reese E. T. 1969. The chitinase of Sarratia marcescens. Canadian Journal Microbiology, 15: 689-696 https://doi.org/10.1139/m69-122

Morton C. O., Hisch P. R., Kerry B. R. 2004. Infection of plant parasitic nematodes by nematoghagous fungi - a review of the application of molecular biology to understand infection processes and to improve biological control. Nematology, 6: 161-170 https://doi.org/10.1163/1568541041218004

Nagami A., Kunwar I. K., Manoharachary C. 2006. Handbook of soil fungi. New Delhi, India

Nguyen N. V., Kim Y. J., Oh K. T., Jung W. J., Park R. D. 2007. The role of chitinase from Lecanicillium antillanum B-3 in parasitism to root-knot nematode Meloidogyne incognita eggs. Biocontrol Science and Technology, 17: 1047-1058 https://doi.org/10.1080/09583150701668658

Ruanpanun P., Tangchitsomkid N., Hyde K. D., Lumyong S. 2010. Actinomycetes and fungi isolated from plantparasitic nematode infested soils: screening of the effective biocontrol potential, indole-3-acetic acid and siderophore production. World Journal of Microbiology and Biotechnology, 26: 1569-1578 https://doi.org/10.1007/s11274-010-0332-8

Safari Motlagh M. R., Samimi Z. 2013. Evaluation of Trichoderma spp. as biological agents in some of plant pathogens. Annals of Biological Research, 4: 173-179

Safavi A., Ren S. X., Huang Z., Wu J. H. 2010. Purification of enzymes related to host penetration and pathogenesis from entomopathogenic fungi. Current Research, Technology and Education Topics in Applied Microbiology and Microbial Biotechnology, 1: 15-22 
Saifullah, Khan N. U. 2014. Low temperature scanning electron microscopic studies on the interaction of Globodera rostochiensis Woll. and Trichoderma harzianum Rifai. Pakistan Journal of Botany, 46 (1): 357-361

Santos M. C., Esteves I., Kerry B., Abrantes I. 2013. Biology, growth parameters and enzymatic activity of Pochonia chlamydosporia isolates from potato cyst and root-knot nematodes. Nematology, 15: 493-504 https://doi.org/10.1163/15685411-00002695

Sankaranarayanan C., Hussaini S. S., Kumar P. S., Rangeswaran R. 2002. Parasitism of Meloidogyne incognita eggs by Fusarium oxysporum and other fungi. Indian Journal of Nematology, 32: 1

Sharon E., Bar Eyal M., Chet I., Herrera E., Strella A., Klelfeld O., Splege Y. 2001. Biological control of the rootknot nematode Meloidogyne javanica by Trichoderma harzianum. Phytopathology, 91: 687-693 https://doi.org/10.1094/PHYTO.2001.91.7.687

Sharon E., Chet I., Spiegel Y. 2009. Improved attachment and parasitism of Trichoderma on Meloidogyne javanica in vitro. European Journal of Plant Pathology, 123: 291-299 https://doi.org/10.1007/s10658-008-9366-2
Tikhonov V. E., Lopez-Llorca L. V., Salinas J., Jansson H. B. 2002. Purification and characterization of chitinases from the nematophagous fungi Verticillium chlamydosporium and $V$. suchlasporium. Fungal Genetics and Biology, 35: 67-78 https://doi.org/10.1006/fgbi.2001.1312

Tobin J. D., Haydock P. J., Hare M. C., Woods S. R., Crump D. H. 2008. Effect of the fungus Pochonia chlamydosporia and fosthiazate on the multiplication rate of potato cyst nematodes (Globodera pallid and G. rostochiensis) in potato crops grown under UK field conditions. Biological Control, 46: 194-201 https://doi.org/10.1016/j.biocontrol.2008.03.014

Zarghani A., Fatemi S., Mahdian S. 2014. Evaluation of the pathogenicity of golden nematode Globodera rostochiensis on potato. Plant Protection (Journal of Agriculture), 37: $11-21$

Zeilinger S., Galhaup C., Payer K., Woo S. L., Mach R. L., Fekete C., Lorito M., Kubicek C. P. 1999. Chitinase gene expression during mycoparasitic interaction of Trichoderma harzianum with its host. Fungal Genetics and Biology, 26: 131-140 https://doi.org/10.1006/fgbi.1998.1111

\title{
Fermento chitinazės aktyvumo ịvertinimas grybụ izoliatuose, gautuose iš auksinio bulvinio nematodo (Globodera rostochiensis)
}

\author{
K. Abbasi ${ }^{1}$, D. Zafari ${ }^{1}$, R. Wick ${ }^{2}$ \\ ${ }^{1}$ Bu-Ali Sina universitetas, Iranas \\ ${ }^{2}$ Stockbridžo žemès ūkio mokykla, Masačiusetso Amherst universitetas, JAV
}

\begin{abstract}
Santrauka
Nematodo kiaušinèlio apvalkalas rodo, kad proteazès ir chitinazès fermentai yra būtini užsikrètimui nematofaginiais grybais, kurių dauguma produkuoja šiuos fermentus. Tyrimo metu siekta ištirti chitinazės veiklą grybų 34 rūšiu izoliatuose, gautuose iš auksinio bulvinio nematodo (Globodera rostochiensis) per dvi grybo augimo dienas (24 ir 96 val.). Chitinazės speficinis aktyvumas nustatytas matuojant redukuojančių sacharidų išskyrimą iš koloidinio chitino, taikant $N$-acetil-gliucozamino-dinitrosalicilato $(540 \mathrm{~nm})$ metodą. Siekiant patvirtinti chitinazės aktyvumą taikytas kolorimetrijos metodas, paremtas vaizdo apdorojimu nustatant spalvų pokyčíus minimalioje sintetinèje terpèje. Tirti 34 izoliatai buvo identifikuoti remiantis morfologiniais ir molekuliniais požymiais, taip pat ir ribosominès DNR vidiniais transkribuotais tarpiklio regionais. Chitinazės specifinio aktyvumo matavimo rezultatai parodè, kad visuose tirtuose izoliatuose jis buvo didesnis po 96 val. nei po 24 val. Maksimalus ir minimalus chitinazès specifinis aktyvumas po 24 val. nustatytas izoliatuose $154\left(0,56 \mathrm{U} \mathrm{mg}^{-1}\right)$ ir $6\left(0,15 \mathrm{U} \mathrm{mg}^{-1}\right)$, po 96 val. - izoliatuose $113(1,02$ $\left.\mathrm{U} \mathrm{mg}^{-1}\right)$ ir $6\left(0,40 \mathrm{U} \mathrm{mg}^{-1}\right)$. Kolorimetrijos metodo rezultatai patvirtino, kad fermentu veikla susijusi su spalvos pokyčiais. Tirti grybų 34 izoliatai buvo suklasifikuoti ị 11 genčių, iš jų dauguma priklausẻ Fusarium rūšiai. Du didžiausio chitinazės fermento aktyvumo izoliatai - 113 (Fusarium oxysporum) ir 154 (Trichoderma atroviridae) gali kontroliuoti auksinį bulvinị nematodą ir būti panaudoti chitinazės fermento, skirto komerciniams preparatams, gamybai.
\end{abstract}

Reikšminiai žodžiai: bulvès, chitinazè, Globodera rostochiensis, grybai. 